\title{
Labour
}

Journal of Canadian Labour Studies

Le Travail

Revue d'Études Ouvrières Canadiennes

\section{Cecil Foster, They Call Me George: The Untold Story of Black Train Porters and the Birth of Modern Canada}

\section{Natasha Henry}

Volume 85, printemps 2020

URI : https://id.erudit.org/iderudit/1070915ar

DOI : https://doi.org/10.1353/1lt.2020.0014

Aller au sommaire du numéro

Éditeur(s)

Canadian Committee on Labour History

ISSN

0700-3862 (imprimé)

1911-4842 (numérique)

Découvrir la revue

Citer ce compte rendu

Henry, N. (2020). Compte rendu de [Cecil Foster, They Call Me George: The Untold Story of Black Train Porters and the Birth of Modern Canada]. Labour / Le Travail, 85, 299-302. https://doi.org/10.1353/llt.2020.0014 d'utilisation que vous pouvez consulter en ligne. 
While it appears at first as if Prairie Fairies might follow a traditional and chronological approach to queer history, Korinek consistently reminds us that it is that very epistemic logic that makes locating non-apparent queer experiences so difficult, as it presupposes a political and spatial trajectory of progress that in many ways mirrors a coming out story. As a highly influential and important product of gay liberation politics in the 1970s, the rhetoric of 'coming out' encouraged thousands of queer people to stop living in the closet, prompting mass migrations to major urban centres; most of which had pre-existing queer subcultures. Scholarship has also had a tendency to overemphasize the idea that movement from rural to urban; shifting from a repressed past to a hopeful future; closeted to "out and proud," are one and the same. Korinek argues that these tendencies contribute to the limited imagination of the prairies as a region blanketed only by farms and a legacy of homophobia. Prairie Fairies resists some of these historiographical trends, asking questions specific to a prairie locales and identities: What kinds of social spaces and connections were enabled through prairie life and prairie identity? How did the location and geography of the prairies vis-à-vis the U.S. and the rest of Canada shape the transfer of ideas and networks between queer scenes? And while it was known that queer cultures existed in cities like Toronto, what were the factors that made people stay?

As evidenced in excerpts from 80 interviews ( 31 of which were conducted by the author), gay, lesbian, and queer people have utilized a range of tactics to navigate their social worlds and to find one another, even in environments that appear to be unfriendly or outright hostile. Those familiar with gay and lesbian history in Canada will undoubtedly recognize the names of some of the individuals profiled: this includes, Chris Vogel, Richard North, and Gens Hellquist, all of whom have spent a significant amount of their lives in the public eye and are openly identifiable as activists. While this is the first longrange and regional study of queer history on the Canadian prairies, Korinek makes clear that there are many gaps left to fill, particularly in terms of including more stories from women and Indigenous people and communities. Unsurprisingly, and thanks to the proliferation of gay and lesbian political organizing, literature, and the declaration of more affirming identity politics, there is far more content available that highlights queer experience in prairie cities after 1969, not to mention more people around to talk about it. Accessing earlier histories is hindered not only by the passage of time and dearth of available witnesses, but also by the dismissal of certain queer experiences as pre-or-apolitical. While the majority of interviewees recruited were white gay men - a common occurrence that in part reflects how experiences of gender, race, and class profoundly shaped the social mobility of queer people - their stories uncover multiple "geograph[ies] of queer socializing." (52-53) These geographies provided the context for a range of sexual practices and expressions of gender nonconformity, in both private and public spaces, long before the days of gay liberation.

Nadine Boulay

Simon Fraser University

\section{Cecil Foster, They Call Me George: The Untold Story of Black Train Porters and the Birth of Modern Canada (Windsor: Biblioasis 2019)}

THE RAILROAD, metaphorically and literally, has figured prominently in nineteenth and twentieth centuries Black history in North America. The 
Underground Railroad, the largest freedom movement in North America, was a secret network of abolitionists who assisted African Americans escaping enslavement in the American South to free Northern states or further north to Canada. It is estimated that between 30,000 and 40,000 freedom seekers entered British North America (Canada) via this clandestine network. Railway terminology such as "Underground Railroad," "conductor," "freight," were used as coded language. Freedom seekers also used the new mode of transportation to escape. In the 1850s, Harriet Tubman used the train across the Niagara River Suspension Bridge to transport freedom seekers into Canada on the last leg of their journey. At the turn of the twentieth century, one of the few places that Black men could find reliable employment in the United States and in Canada was on the railway.

In his latest book, They Call Me George: The Untold Story of Black Train Porters and the Birth of Modern Canada, Cecil Foster gives an historical account of the labour history and working lives of Black porters in Canada and relates its/this history's intricate connection to Canadian immigration history. This lesser known historical narrative is told through individual stories of Black men who were employed as sleeping car porters. Foster opens the book with an introduction to the April 27, 1954 delegation to Ottawa by members of the Negro Citizenship Association, Black community activists and supporters, and some of their Jewish allies as the backdrop to the story. The delegates travelled by train from Toronto to Ottawa to demand that the federal government change the exclusionary definition of British subjects that blocked Black and African subjects in the Commonwealth from immigrating to Canada, and to open up the country's doors to racialized people from all around the world. The significance of this running narrative thread is that many of the organizers and delegates were porters and they travelled by train as a symbolic act.

The text details the working lives of sleeping car porters for readers to gain an understanding of what their work entailed. The job of train porters was to assist sleeping car passengers on their train travels from their arrival at the station to their departure. Red caps hauled luggage, made up sleeping berths, provided a range of personal services such as shining shoes and ironing clothes, served meals to passengers, and kept the cars clean. From the turn of the twentieth century through to the late 1960s, the occupation of porter was almost exclusively held by Black men. Foster notes that the term "sleeping car porter" became synonymous with "Black." (45) Their working conditions were deplorable. Porters worked long hours and were on-call 24-hours a day, sleeping only 3-4 hours a night as they criss-crossed the country. For this they received paltry pay. Porters were forced to do unpaid work and did not receive overtime pay. They were only paid for hours worked on the train, not for the time they spent preparing for their shifts or cleaning up after their shift ended. While some Black porters held seniority, most were intentionally designated as casual and on-call employees. They did not receive any extended health benefits, no leave, no pension, and lived under the constant threat of dismissal for even the smallest infractions. Adding to these conditions was the fact that railway trade unions made it their mandate not to protect the rights of Black workers.

Foster's careful analysis of the intersection of race, gender, and class in the experiences of Black porters and Black Canadians more broadly, contributes to the study of Black labour in Canada. His research demonstrates how employment opportunities were dictated by race 
and that a racial hierarchy was firmly entrenched in the organizational structure of Canadian railway companies to maintain a white social order that mirrored a racist, anti-Black Canadian society. As Foster explains, politicians such as Prime Minister Wilfrid Laurier and the Minister of Railways were guided by a vision of Canada as a "White Man's Country" and as a consequence, enacted a "colour line" in railway employment and immigration for most of the twentieth century. Foster describes how these racial barriers were designed to restrict and control the employment and social mobility of Black Canadians and to maintain the white dominant status quo.

They Call Me George discusses how Black men and women had severely limited job opportunities, were relegated to menial jobs largely in the service sector, and were generally excluded from the wider labour market. Foster deepens this trajectory of his analysis by tracing the continuum of the service status imposed on Black people since during slavery. On the railway, Black men were only employed as porters and waiters; other positions such as sleep car conductors, dining car stewards, any operational positions, and supervisory roles were strictly reserved for white men. Black porters were objectified and commodified. Black labour was associated with convenience, luxury for white passengers. These men were called George's Boys or simply George, a reference to the originator of the sleeping car George Pullman and rooted in the paternalistic practice during slavery when the enslaved were name after their enslavers.

This was the racial codification of labour. Foster illustrates how the racial oppression of Black porters was a component of the operations strategies of Canada's national railways that were intended to build a nation. Additionally, he describes how Black labour and Black
Canadians' persistent advocacy for racial justice contributed to Canadian modernity.

Foster's investigation also illustrates how the railway conglomerates, trade unions, and the federal government colluded to limit Black workers to porter services and to deny them workplace protections because of their race. In 1908, the Canadian Brotherhood of Railway Employees (CBRE), the CPR, the $\mathrm{CNR}$, and the office of the Minister of Railways conspired to restrict membership to white workers. This restriction lasted into the 1960s. In the parallel story of the 1954 delegation to Ottawa, the author outlines how Canada's immigration policy was also discriminatory. The 1910 Immigration Act barred immigrants from races deemed undesirable from entering Canada. This applied to African descended British subjects and as a consequence, a very small number of Black people gained entry into Canada during the following decades. To institute even tighter measures to block Black people from immigrating into Canada, in 1911 an Order-in-Council that banned "any immigrants belonging to the "Negro race"" for one year was passed.

Although the renumeration was quite low and the working conditions were less than ideal, employment as a porter was one of the best jobs available for Black men and helped to elevate Black families into the middle class. Black men from across Canada as well as from the United States and the Caribbean sought employment as porters. Foster demonstrates how many porter families were able to purchase homes and to send their children to post-secondary schools and accomplish some measure of stability.

These men not only wanted more for themselves, they wanted more for their fellow porters, for their communities, and for their country and set out to effect change. Foster represents Black 
porters as historical agents, who engaged in persistent political activism. He details how Black porters established their own unions, the first in 1917 when the Winnipeg-based Order of Sleeping Car Porters was formed. Then in 1939 Black porters sent a letter to Asa Philip Randolph, head of the Brotherhood of Sleeping Car Porters in the United States and prominent Black civil rights activist, asking for his assistance in mobilizing porters to join the BSCP. The union for Black railway employees became certified in Canada on May 18, 1945. The BSCP operated six divisions that served its Black members across Canada until 1978. The union negotiated contracts with the railway companies that resulted in some improvements and benefits in the collective agreement for Black porters. Changes included better working conditions, sleep breaks, and fairer and more transparent disciplinary measures. Other gains included pay increases, overtime pay, paid vacation, and the ability to place name plaques in sleeping cars so that passengers would know their names.

They Call Me George explores the personal lives and activism of a number of porters including Bromley Armstrong, Stanley Grizzle, Harry Gairey, Cottrell Lawrence Dellums, Charles Ernest Russell, and Donald Moore who played a role in the formation of the BSCP and in the protest trip to Ottawa that influenced a new immigration policy that relaxed its xenophobic practices and became the basis for the points-based system. Foster interviewed surviving porters and drew on a variety of archival sources including newspaper articles, parliamentary speeches, government records, and trade union documents to chronicle their experiences.

Foster contends that Black train porters are deserving of recognition for their vision of a Canadian state that was multicultural and inclusive and for their active role in helping to make that ideal a reality, a case that he carefully lays out in the book. They Call Me George is valuable reading for students of Black Canadian studies, Canadian history survey courses, and courses in Canadian labour history and immigration.

Natasha Henry

York University

\section{Marian Jago, Live at the Cellar: Vancouver's Iconic Jazz Club and the Canadian Co-operative Jazz Scene in the 1950s and '60s (Vancouver: UBC Press 2018)}

LIVE AT THE CELLAR adds depth and resonance to the Canadian jazz soundscape by decentering the two cities most commonly associated with this music north of the border with the United States: Toronto and Montreal. In this book, Marian Jago, lecturer at the University of Edinburgh, examines the burgeoning scenes that developed around artist-run clubs in Vancouver (The Cellar, Black Spot, and Flat Five, among others), Edmonton (Yardbird Suite), Calgary (Foggy Manor), and Halifax (777 Barrington Street) from the mid-1950s to the late 1960s. The Cellar occupies centre stage in this social history of youth culture and jazz cooperatives, because of its significance as a cultural hub for musicians and non-musicians alike as well as its role in paving the way to a pan-Canadian scene rooted in regional networks. The book's accessible prose and lively narrative, augmented with the voice of many protagonists, aims to speak to a wide readership. In the process, it provides substance to the symbolic importance of the scenes it discusses while enriching our understanding of the transnational circulation of jazz as both a social practice and an art form. 